\title{
ERGONOMIC EXERCISES TO DECREASE JOINT PAIN SCALE AND MUSCLE STRENGTH IN ELDERLY
}

\author{
(Senam Ergonomis terhadap Penurunan Skala Nyeri Sendi dan \\ Kekuatan Otot pada Lanjut Usia)
}

\author{
Titih Huriah*, Ema Waliyanti*, Afiani Septina Rahmawati**, Yuliana Mz Matoka** \\ *Lecture in community nursing departement PSIK FKIK UMY \\ **Students in PSIK FKIK UMY \\ E-mail: titih_psikumy@yahoo.com
}

\begin{abstract}
ABSTRAK
Pendahuluan. Data epidemiologi menunjukkan terdapat peningkatan prevalensi nyeri kronik dan kelemahan otot pada lanjut usia. Terapi modalitas non farmakologi merupakan komponen manajemen multimodal yang sangat penting dalam mengatasi nyeri, termasuk terapi aktivitas fisik Senam Ergonomis. Penelitian ini bertujuan untuk mengetahui pengaruh terapi aktivitas senam ergonomis terhadap penurunan skala nyeri sendi dan peningkatan kekuatan otot pada lansia dengan degeneratif sendi. Metode. Penelitian ini adalah study intervensi berupa penelitian kuantitatif dengan rancangan Quasy Experiment Design: Pretest-Posttest Control Group Design. Sampel pada penelitian ini sebanyak 50 orang lansia dengan masing-masing 17 lansia sebagai kelompok intervensi dan 33 lansia sebagai kelompok kontrol. Pengambilan sampel menggunakan teknik purposive sampling. Analisis data yang digunakan adalah uji t, Wilcoxon dan Mann Whitney. Hasil. Setelah 4 minggu intervensi senam ergonomis, terdapat pengaruh terapi aktivitas senam ergonomis terhadap penurunan skala nyeri sendi pada lansia dengan degeneratif sendi dengan nilai P value $0.0001(\alpha<0,05)$ dan peningkatan kekuatan otot dorongan (P value 0,0001) dan peningkatan kekuatan otot tarikan (P value 0,002). Diskusi. Terapi aktivitas senam ergonomis berpengaruh secara signifikan terhadap penurunan nyeri sendi dan peningkatan kekuatan otot pada lanjut usia dengan degeneratif sendi.
\end{abstract}

Kata kunci: degeneratif sendi, lansia, nyeri sendi, kekuatan otot, senam ergonomis

\section{ABSTRACT}

Introduction. Epidemiological data showed an increased prevalence of chronic pain and weakness in the elderly. Nonpharmacological modality therapy is a component of multi modal management that very important for pain management, including Ergonomic Exercises. The aims of the study was to determine the effect of activity therapy ergonomic exercises to decrease joint pain scale, and to increase muscle strength in elderly with joints degenerative. Method. Quasi-experimental with pretest-posttest control group design was carried out in this study. Purposive sampling was used to identify the study subjects. A sample of 50 elderly was included in the study for experimental (17) and control (33) groups. Sampling technique used purposive sampling. T-test, Wilcoxon, and two sample Wilcoxon rank-sum, tests were used to analysis the data. Results. During the four weeks intervention of ergonomic exercise, there were significant decreases in scale joint pain in elderly with degenerative joint by $P$ value $0.000(\alpha<0.05)$, and increases in muscle strength by $P$ value 0.002 for muscles pull and $P$ value 0,0001 for muscles push. Discussion. Activity therapy of an ergonomic exercise has significant influence to decrease joint pain scale and to increase muscle strength in elderly with degenerative joints.

Keywords: joint degenerative, elderly, joint pain, muscle strength, ergonomic exercises

\section{INTRODUCTION}

Aging is a characteristic of the dynamical physiological process and it experiences the irreversible differences in the physiological functions of the elderly (Rastogi \& Meek, 2013). It will impact on various aspects, especially in terms of the health aspect. the epidemiological data support the prevalence of the enhancement of the chronic pain and weakness in the elderly. The elderly often have multiple chronic illnesses pathologies, the changes of body function, and weakness (Rastogi \& Meek, 2013). One of the chronic diseases that can cause the sensation of pain in the elderly is Rheumatoid Arthritis (RA) (Cooney et al, 2010). In addition, the elderly are particularly susceptible to the degenerative joint disease (Fox et al., 2004).

Modality therapy in the elderly pain can be categorized in several aspects. A multidisciplinary approach is recommended to investigate the possibility of optimal pain 
management, such as pharmacotherapy (the most commonly used treatment), psychological support, physical rehabilitation, and interventional procedures. Pharmacological therapy which is often used are NSAIDs, muscle relaxants, opioids, and adjuvant therapy (Kaye et al, 2010).

Non-pharmacological modality therapy is the important component of multimodal management as it helps to cope the pain better by the improvements in daily functioning, which includes the physical therapy (Rastogi \& Meek, 2013). The physical exercise therapy can reduce joint pain intensity on the elderly (Permana, 2011).

The Ergonomics exercise is the therapy of physical activity (Fahmi, 2010). The ergonomics exercises is inspired by the movement of sholat (prayers). The prayers movements contain autoregulation and adaptation of the human body with the brain as the central controller (Sagiran, 2006). The ergonomics exercise is a exercises movement which can immediately open, clean, and activate the entire systems of the body such as the cardiovascular system, urinary, reproductive (Wratsongko, 2010).

From the preliminary survey, it is obtained the highest number of elderly in 2012 were in the region of Health Center of Kasian II with 10701 inhabitants with health services of $39.43 \%$ (Bantul District Health Profile, 2013). The number of elderly is quite large if it is compared with the health problems faced include degenerative joint problems. The survey of the health center of Kasian II shows the data obtained that the highest prevalence of degenerative joint are in the neighborhood health center of Aster Dusun Padokan Kidul, neighborhood health center of Flamboyan Dusun Onggobayan, and neighborhood health center of Menur I Dusun Jomegatan. The background of the problems and some researches related to this study direct the researcher to determine the effect of therapeutic activity of Ergonomics Exercises to decrease joint pain scale and increase the muscle strength in elderly with the degenerative joints in health center of Kasian II.
Based on the description of the background, the research question is formulated as "can the physical activity therapy of ergonomic exercises reduce joint pain scale and increase muscle strength in elderly with degenerative joint?". The purpose of this study was to analyze the effect of therapy of ergonomic exercise to reduce the scale of joint pain and increase the muscle strength in elderly with degenerative joints in health center of Kasian II Bantul, Yogyakarta.

\section{METHODS}

The research was designed as the intervention studies of Queasy Experiment Design: Pretest-Posttest Control Group Design. The population was the elderly who have degenerative joints. Based on the data in 2012 in Kasian II Health Center and the preliminary survey result, the numbers of elderly with degenerative joint in Kasihan II health center are 698 elderly.

The assessment of pain scale was based on the results of interviews using a numeric scale (numeric rating scale). Meanwhile, the exclusion criteria in this study were elderly with degenerative joints that have heart disease, fractures, or severe pain and had to be hospitalized, the elderly who experience shortness of breath on exertion is also included in this criterion.

The study used three groups: the intervention group and 2 control groups. The total numbers of samples in the intervention and control groups were 54 people who need to be re-validation. The sampling technique of the population used the purposive sampling and the determination techniques for each group (randomization) uses random assignment.

This therapy was conducted twice in a week for 1 month at the elderly who experience the joint pain and it will be conducted directly by the researcher. The joint pain was a manifestation of degenerative joint joints as measured by the Numeric Rating Scale. Muscle strength was a measurement of the static strength of the muscle, which was the back extension strength and leg extension (back and leg dynamometer), force push and 
pull the shoulder (pull and push dynamometer), hand grip strength (handgrip dynamometer).

In this study, the data analysis was conducted by comparing the situation before and after treatment. In addition, a comparison was also made between the two groups (intervention and control). The data analysis used the t-test statistical test that has a 95\% confidence level. In addition to the t test, researchers also used parametric Wilcoxon test and the Mann Whitney test.

\section{RESULT}

Table 1. Distribusi Mean Scale Level of Joint Pain In Sergo Group (Intervention), SKJ and the Elderly exercise (Control group)

\begin{tabular}{lllll}
\hline \multirow{2}{*}{ Groups } & \multicolumn{4}{c}{ Pain scale } \\
\cline { 2 - 5 } & Mean \pm SD & $\mathbf{9 5 \%}$ CI & Min & Max \\
\hline Sergo & $3,76 \pm 3,65$ & $(3,20,4,36)$ & 2,00 & 6,00 \\
$\quad$ Pretest & $1,06 \pm 1,25$ & $(0,42,1,70)$ & 0,00 & 4,00 \\
$\quad$ Posttest & & & & \\
SKJ & $4,53 \pm 1,18$ & $(3,92,5,14)$ & 3,00 & 7,00 \\
$\quad$ Pretest & $3,88 \pm 1,41$ & $(3,16,4,61)$ & 1,00 & 6,00 \\
$\quad$ Posttest & & & & \\
Eldery exercise & $4,57 \pm 1,22$ & $(3,87,5,28)$ & 3,00 & 7,00 \\
$\quad$ Pretest & $3,71 \pm 1,38$ & $(2,92,4,51)$ & 1,00 & 5,00 \\
$\quad$ Posttest & & & & \\
\hline
\end{tabular}

Table 2. The Pull Muscle Strength Mean Distribution on Sergo Group (Intervention), SKJ and Elderly Exercise (Control group)

\begin{tabular}{lcccc}
\hline \multirow{2}{*}{ Groups } & \multicolumn{4}{c}{ Pain scale } \\
\cline { 2 - 5 } & Mean \pm SD & $\mathbf{9 5 \%}$ CI & Min & Max \\
\hline Sergo & & & & \\
Pretest & $8,06 \pm 3,65$ & $6,18,9,93$ & 3,50 & 16,50 \\
$\quad$ Posttest & $9,15 \pm 3,66$ & $7,27,11,03$ & 3,50 & 16,50 \\
\hline SKJ & & & & \\
\hline Pretest & $5,91 \pm 2,59$ & $4,58,7,24$ & 2,00 & 10,50 \\
Posttest & $6,12 \pm 3,11$ & $4,52,7,72$ & 2,00 & 13,50 \\
\hline Eldery exercise & & & & \\
\hline Pretest & $5,75 \pm 2,58$ & $4,26,7,24$ & 2,00 & 10,50 \\
Posttest & $5,54 \pm 2,93$ & $3,84,7,23$ & 2,00 & 13,50 \\
\hline
\end{tabular}

Table 3. Analysis of the Wilcoxon Test Pain Scale In Sergo Group (Intervention), SKJ and Elderly Exercise (Control group)

\begin{tabular}{lccc}
\hline \multicolumn{1}{c}{ Variable } & \multicolumn{3}{c}{ Wilcoxon Test } \\
\cline { 2 - 4 } & Mean Rank & $\mathbf{Z}$ & P value \\
\hline $\begin{array}{l}\text { Sergo Group } \\
\quad \text { Pre-post test of pain scale }\end{array}$ & 9,00 & $-3,65$ & 0,0001 \\
$\begin{array}{l}\text { SKJ Group } \\
\quad \text { Pre-post test of pain scale }\end{array}$ & 5,88 & $-2,07$ & 0,039 \\
$\begin{array}{l}\text { Eldery Exercise } \\
\quad \text { Pre-post test of pain scale }\end{array}$ & 5,19 & $-2,34$ & 0,020 \\
\hline
\end{tabular}


Ergonomic Exercisesto Decrease Joint Pain Scale (Titih Huriah, dkk.)

Table 4. Analysis of Paired T-Test Muscle Strength Push and Pull In Sergo Group (Intervention), SKJ and Elderly Exercise (Control group)

\begin{tabular}{lccc}
\hline \multicolumn{1}{c}{ Variable } & \multicolumn{3}{c}{ Paired t-test } \\
\cline { 2 - 4 } & Mean \pm SD & T & P value \\
\hline Sergo Group & $-1,09 \pm 0,91$ & $-4,96$ & 0,00001 \\
Pre-post test of the muscle pull & $-0,21 \pm 1,75$ & $-3,89$ & 0,001 \\
Pre-post test of the muscle push & & & 0,634 \\
\hline SKJ Group & $-1,32 \pm 1,40$ & $-0,49$ & 0,707 \\
\hline Pre-post test of the muscle pull & $0,12 \pm 1,27$ & 0,38 & 0,633 \\
Pre-post test of the muscle push & & & 0,183 \\
\hline Eldery Exercise Group & $0,21 \pm 1,64$ & 0,49 & \\
\hline Pre-post test of the muscle pull & $0,43 \pm 1,14$ & 1,41 & \\
Pre-post test of the muscle push & & & \\
\hline
\end{tabular}

Table 5. Analysis of the Mann-Whitney Test Pain Scale In Sergo Group (Intervention), SKJ and Elderly Exercise (Control group)

\begin{tabular}{lccc}
\hline \multirow{2}{*}{ Variable } & \multicolumn{3}{c}{ Mann-Whitney Test } \\
\cline { 2 - 4 } & Mean Rank & $\mathbf{Z}$ & P value \\
\hline Pain Scale & $31,60,11,56$ & $-4,83$ & 0,0001 \\
\hline
\end{tabular}

Table 6. Analysis of the Independent T-Test Muscle Strength Push and Pull in Sergo Group (Intervention), SKJ and Elderly exercise (Control group)

\begin{tabular}{lccc}
\hline \multirow{2}{*}{ Variable } & \multicolumn{3}{c}{ Independent t-test } \\
\cline { 2 - 4 } & Mean Diff & T & P value \\
\hline The pull muscle strength & 3,29 & 3,37 & 0,002 \\
The push muscle strength & 5,11 & 5,69 & 0,00001 \\
\hline
\end{tabular}

The intervention and control groups are equally seen a decrease in the pain scale, but in the intervention group, the elderly pain scale decreases more significantly. The results of the analysis related to the average muscle strength indicates the strength of the pull of the muscle in the control group have a mean, minimum and maximum values which are almost, whereas in the group average Sergo pull muscle strength was 8-9. In the group of Sergo and SKJ, it is seen an increase but in the elderly exercise no increasing of the pull muscle strength. The results of the analysis of the Wilcoxon test shows a decrease of pain scale in the three groups with $\mathrm{P}$ Value of $<0.05$. The results of the analysis of Paired T-Test of the push and pull muscle strength shows an increase in muscle strength push to pull in ergonomic exercise group with $\mathrm{P}$ Value of $<0.05$, whereas in the SKJ and the elderly exercise no increase in muscle strength both in pull and push strength. The results of the analysis of the Mann-Whitney test shows that there were differences in pain scale in all three groups with the P Value of $<0.05$. This indicated ergonomic exercises can reduce pain.

The results of the Independent T-Test analysis of muscle strength push and pull showed there were differences in the three groups with a $\mathrm{P}$ Value $<0.05$. This indicated ergonomic exercises can increase muscle strength either pull or push.

\section{DISCUSSION}

This research was conducted in AprilMay 2014. At the beginning of the research, there were 54 elderly as the sample with the distribution of 18 elderly per group, but due to the sample who dropped out, the sample size to 50 elderly were divided into one control group 
totaled 17 elderly, 2 control group as 14 elderly and intervention amounted to 17 elderly. The average age of the sample in this study was 65 years old. The age of 65 years old becomes one of the factors that led to the emergence of joint problems due to physiological changes in the elderly.

Characteristics of female respondents were bigger than men, both in the control and intervention group. This was supported by studies Sugiura \& Demura (2012) which states that the prevalence of degenerative joint pain especially in the joints, especially arthritis is more common in women than men. It is also supported with the demographic data where the number of elderly female due to the larger than life expectancy of women is longer than men (11.29 million versus 9.26 million). Therefore, the problem of the elderly in general in Indonesia is dominated by women. In addition, women prone to osteoarthritis which is caused by a decrease in the hormone estrogen during menopause, these hormones play a role in the loss of bone mass resulting in a sensation of joint pain in the elderly (Lukman \& Ningsih, 2011).

Characteristics of elderly, generally, do bot work i.e. Housewife (IRT) in both groups. According to the Statistics Agency data, the average elderly already full of duty and more frequent to run the activity in domestic work. This limited activity can refer to the reduction in synovial fluid. Reduced synovial joints will cause pain and stiffness of the joints section (Sudoyo, 2006).

The results of the different test characteristics of the respondents shows no difference between groups Sergo, SKJ group and the group of elderly neighborhood health center. The result of this analysis shows three homogeneous groups. Homogeneity is possible because the elderly group comes from the environment with the same characteristics that are in the rural areas (rural) and it is under the guidance of Kasian II health center.

In the intervention and control groups were equally seen a decrease in the pain scale, but in the intervention group, the elderly pain scale decreased more significantly. Both groups experienced a decrease in the possibility of behavior that can affect the decrease in perceived joint pain scale. The pain is still in the mild and moderate scale due to pain caused by arthritis which can still be controlled. In the journal, Ayu (2012) explains that average of the elderly who experience joint pain knee pain scale ranging from 1-6. The range of joint pain scale is the same as the pain scale range in the study that the researchers conducted with an average of 3-4.

Joint pain in the elderly occur in almost all the elderly, especially due to degeneration of the joints and bones. In the elderly, the decreased function of the musculoskeletal system is as a result of changes in collagen, the impact of these changes is a reduction in the flexibility of joint. Besides, the erosion of the joint capsules leads to decreased movement of joints and causes widespread pain (Azizah, 2011). Fox et al (2004) adds that in the musculoskeletal impairment caused due to age is a degenerative joint disease and a common complaint is pain and stiffness of the joints.

The results of the analysis related to the average muscle strength indicates the strength of the pull of the muscle pull in the control group had a mean, minimum and maximum values which are almost the same, whereas in the group average Sergo pull muscle strength is 8-9. In the control group of elderly tug muscle strength is 5-6 with an increase of only 1-2. The same thing happened to the push muscle strength. It is in the causes of agerelated musculoskeletal changes in the elderly include decreased height, redistribution of subcutaneous fat and muscle mass, increased bone porosity, muscle atrophy, slow movement, reduction in strength, and stiffness of the joints. Changes in the bones, muscles and joints resulted in a change of appearance, weakness, and slow movements that accompany aging (Stanley and Beare, 2006).

Based on bivariate analysis test control and intervention groups with the Wilcoxon analysis shows that the $\mathrm{P}$ value of the pre-test and post-test SKJ group is 0039, a group of elderly gymnastics $P$ value of 0.020 , while the pre-test and post-test in the intervention group is 0.0001 , all of the groups show the $\mathrm{P}$ 
value of $\leq 0.05$, so the results of the study in all three groups, the control and the intervention shows a decrease in pain. Some seniors seeking health provider when experiencing severe pain and responds to pain by using drugs at prescribed. The pain is often the elderly feel very disturbing daily activities due to pain which is disturbing the elderly often seek treatment by themselves.

Other factors affecting the joint pain in the elderly, among others, the level of education, BMI, and activity. The level of education will have an effect in the understanding of the knowledge acquired. The elderly with low levels of education are more at risk of arthritis pain. Knowledge plays an important role in improving health in the elderly, including in relation to this arthritishal will affect the elderly in the treatment of arthritis management. Body Mass Index (BMI) effect on joint pain due to arthritis, overweight BMI will improve arthritis symptoms including joint pain sensation. This happens because the heavier the load the foundation thus increasing the burden of friction in the joints (Wang et al, 2009). Another factor is physical activity or exercise that will train the body to move so as to give effect in the production of synovial fluid which serves as a lubricant and prevents friction in the joints that can lead to pain. Activities will also activate the immune system and prevent inflammation in the joints which have one of the signs and symptoms of joint pain (Robbins et al, 2009).

Movements in Ergonomic exercise is included in Non-Weight Bearing movement because the movement is designed to be simple, brief, and do not use a load that can be done in a short period of time (Griwijono \& Finger, 2012). The Ergonomic exercise is practiced for 8 sessions in 4 weeks. The descriptive research Iversen et al, (2013) explains that the exercise of moderate intensity activity can be practiced regularly 2 times a week to reduce pain in the joints. According to Ayu (2012) 15 elderly who experience joint pain effectively decreased after elderly exercise within 15-45 minutes for 6 consecutive days. The exercise is practiced to reduce the pain of osteoarthritis can be effective if it is practiced in a long time that for 2 months. Wang et al (2009) also said that the 40 respondents in the form of Tai Chi exercise activity within 60 minutes effectively practiced for 2 times in 12 weeks.

Physical activity in the form of exercise will reduce the sensation of joint pain. The previous studies describes physical activity can improve quality of life for people with arthritis. In addition, physical activity will provide a positive effect on muscle strength and function, and mood in the elderly. Physical activity can be in a elderly exercise, which is proven to reduce joint pain, amounting to $86.7 \%$ of respondents had joint the pain scale and by $13: 330 \%$ of respondents had joint the pain scale 1 after the intervention in the form of elderly exercise (Ayu, 2012).

The results of the analysis of Paired TTest push and pull muscle strength shows an increase in muscle strength and push to pull ergonomic exercise group with $\mathrm{P}$ Value $<0.05$, whereas in the SKJ and elderly exercise group, there is no the increase in muscle strength both in pull and push strength. The results of Independent T-Test analysis of muscle strength push and pull shows there are differences in the three groups with a $P$ Value of $<0.05$. This indicates ergonomic exercises can increase muscle strength either pull or push.

The Ergonomic exercise or physical activity can stimulate the increase activation of chemical neuromuscular and muscular. Stimuli which are carried by nerve cells and muscle fibers causes the release of $\mathrm{Ca}$ ions bind to molecules of small filaments which allows the interaction of actinic and myosin filaments in the sarcoma, resulting in a small shift then there is a contraction of myofibrils and muscle fibers. The mechanism through muscular when Muscles needs the energy to contract causing cellular oxidative metabolic processes to form adenosine triphosphate (ATP) which is used as energy when the muscles contract. The energy in different muscles need to be increased during the physical activity. In order to maintain muscle strength and function, it should always be trained. When muscle bears again reached maximum or near-maximum voltage for a long time and regularly, it will cause the muscle transverse incision which 
will be enlarged so as to increase the muscle mass and muscle strength (Sherwood, 2011; Brunner and Suddarth, 2001).

Other factors that affect the muscle strength in the elderly are physical activity, obesity, and muscle injury. Intense physical activity can maintain muscle strength in the elderly. Obesity in the elderly can affect the mobility and muscle strength, obesity predispose the elderly to undergo ligament instability, especially in the lower back and other joints that hold the weight of the body. Muscle injury can lead to immobilization, causing loss of muscle mass and strength (Brunner and Suddarth, 2001; Stanley and Beare, 2006).

Physical activity in the form of exercise can increase muscle strength in the elderly. Previous studies Safa'ah (2013) describes the effect of range of motion exercises which are carried out on a regular basis can increase the muscle strength in the elderly, collecting the data in this study using a checklist and sheets of observations which is made during the 3 months.

Jahagirdar Research (2010) EMGbiofeedback intervention and exercise balls for 12 weeks to improve morbidity, muscle strength and functionality. In this study, there are some significant improvements to the power of the tibialis anterior muscle-muscle, thigh muscle strength, thus, the study of the training tibial sufficient causes effective force. Research Kawanabe et al (2007) on the effects of exercise body vibration (WBV) and muscle strengthening exercises which is practiced with a duration of 4 minutes can obtain hormonal profile and neuromuscular can improve the response performance immediately after the occurrence oculist exercises that stimulate blood vessel growth hormone testosterone which plays a role in the process anabolitik muscle action.

In this study, researchers uses a method of therapy in the form of exercise activities ergonomically to increase muscle strength in the elderly between the two groups by measuring muscle strength to push and pull with the $\mathrm{P}$ Value of dynamometer result of there is a significant influence on the improvement of both traction and push muscle strength in elderly after being given the intervention of the ergonomic exercises during meetings 8 times.

\section{CONCLUSION}

There was an ergonomic exercises therapy can to declined the joint pain scale and increased of pull and push muscle strength in the elderly with degenerative joints.

\section{RECOMMENDATION}

It is needed a program that trains physical activity of elderly in the form of exercises that can be used as support in reducing joint degenerative joint pain in the elderly. The elderly also must be active and independent in an effort to improve their health status.

\section{REFERENCES}

Ayu \& Warsito. (2012). Pemberian Intervensi Senam Lansia Pada Lansia Dengan Nyeri Lutut. Jurnal Nursing Student. Vol. 1.

Azizah. (2011). Keperawatan Lanjut Usia. Yogyakarta: Graha Ilmu.

Campbell and Stanley. (1963). Experimental and Quasy Experimental Design for Research. Boston: Houghton Mifflin Company.

Cooney, Law, Matschke, Lemmey, Moore, Ahmad., et al. (2011). Benefits of Exercise in Rheumatoid Arthritis. SAGE-Hindawi Access to Research.

Depkes. (2013). Profil Kesehatan Indonesia 2012. Jakarta: Pusat Data Kesehatan Depkes.

Departemen Kesehatan Republik Indonesia. (2006). Pedoman Kesehatan Olahraga di Puskesmas. Jakarta. Dari http:// perpustakaan.depkes.go.id/diakses 25 Desember 2013.

Dinas Kesehatan Bantul. (2013). Profil Kesehatan Kabupaten Bantul. Departemen Kesehatan Kabupaten Bantul.

Dinas Kesehatan DIY. (2012). Profil Kesehatan Penduduk Indonesia. Departemen Kesehatan Provinsi DIY. 
Fahmi. (2010). Pengaruh Senam Ergonomis pada Penderita DM Tipe 2 terhadap Kadar Glukosa Darah Puasa dan Kadar Glukosa 2 Jam Postprandial. Skripsi Strata Satu, Universitas Muhammadiyah Yogyakarta. Yogyakarta

Fox, Taylor, Yazdany. (2004). Arthritis for Dummies $2^{\text {nd }}$ Edition. Canada: Wiley Publising.

Giriwijoyo Santosa dan Sidik Zafar Dikdik. (2012). Ilmu Kesehatan Olahraga. Bandung: PT Remaja Rosdakarya.

Iversen \& Bawerman. (2013). Recommendations and the state of the evidence for physical activity interventions for adults with rheumatoid arthritis: 2007 to present. NIH Public Access. 489-503.

Jahagirdar Shriharsh. (2010). Training Eldery For Mobility and Strength Using EmgBiofeedback and Swiss Ball/Peanut Ball Exercises. The Indian Journal of Occupational Therapy. Dari medind. nic.in/iba/t10/i1/ibat10ilp17.pdf diakses 28 juni 2014.

Kaye, Baluch, Scott. (2010). Pain Management in the Elderly Population: A Review. The Ochsner Journal. 10:179-187.

Kazuhiro Kawanabe, Akira Kawashima, Issei Sashimoto, Tsuyoshi Takeda, Yoshihiro Sato dan Jun Iwamoto. (2007). Effect of Whole-Body Vibration Exercise and Muscle Strengthening, Balance, and Walking Exercise on Walking Ability in the Elderly. Departement Of Sport Medice. Dari www.vibratech.co.il/ .../034.vibration-exercise-musclestrengthening diakses 21 Juni 2014.

Kementerian Kesehatan RI. (2013). Buletin Jendela Data dan Informasi Kesehatan. Diakses pada 19 November 2013.

Lukman \& Ningsih. (2011). Asuhan Keperawatan pada Klien dengan Gangguan Sistem Muskuloskeletal. Jakarta: Salemba Medika.

Permana. (2011). Pengaruh Terapi Latihan Fisik terhadap Intensitas Nyeri Pada Lansia di Panti Sosial Tresna Werdha Budi Luhur Yogyakarta. Skripsi Strata Satu, Universitas Muhammadiyah Yogyakarta.Yogyakarta.
Rastogi \& Meek. (2013). Management of chronic pain in elderly, frail patients: finding a suitable, personalized method of control. Dove Medical Press Ltd, $37: 46$.

Robbins. (2012). Intisari Patologi. Tangerang: Binarupa Aksara.

Safa'ah. (2013).Pengaruh Latihan Range of Motion terhadap Peningkatan Kekuatan Otot Lanjut Usia di UPT Pelayanan Sosial Lanjut Usia (Pasuruan) Kec. Babat Kab Lamongan. Dari www. kopertis7.go.id/uploadjurnal diakses 28 juni 2014.

Sagiran. (2012). Mukjizat Gerakan Shalat. Jakarta: Qultum Media.

Sherwood L. (2001). Fisiologi Manusia dari Sel ke Sistem. Jakarta: Penerbit Buku Kedokteran EGC.

Slamet Sudarsono. (2011). Penyusunan Program Pelatihan Berbeban untuk Meningkatkan Kekuatan. Jurnal Ilmiah Spirit, ISSN Vol. 11. Dari ejournal.utp. ac.id/index.php/JIS/article/view/35/33 diakses 23 November 2013.

Smaltzer S.C., Bare B.G. (2002). Keperawatan Medikal Bedah Brunner dan Suddarth. Penerjemah: Andry Hartono, H.Y. Kuncara, Elyana S.L.S., dan Agung Waluyo. Jakarta: EGC.

Stanley \& Beare. (2006). Buku Ajar Keperawatan Gerontik. Jakarta: Penerbit Buku Kedokteran EGC

Sudoyo W Aru, dkk. (2006). Buku Ajar Ilmu Penyakit Dalam Cetakan Kedua. Jakarta: Pusat Penerbitan Departemen Ilmu Penyakit Dalam Fakultas Kedokteran Universitas Indonesia.

Sugiura dan Demura. (2012). The Effects of Knee Joint Pain and Disorders on Knee Extension Strength and Walking Ability in the Female Elderly. Japan: Kanazawa University. Diakses pada 1 Juni 2014.

Wang et al. (2009). Tai Chi is Effective in Treating Knee Osteoarthritis: A Randomized Controlled Trial. Manuscript.

Wratsongko. (2010). Shalat Jadi Obat. Jakarta: Elex Media Komputindo. 